\title{
Relationship of circulating cell-free DNA levels to cell-free fetal DNA levels, clinical characteristics and laboratory parameters in preeclampsia
} Levente Lazar*1 ${ }^{1}$ János RigóJr ${ }^{1}$, Bálint Nagy ${ }^{1}$, Krisztián Balogh ${ }^{2}$, Veronika Makó ${ }^{3}$, László Cervenak ${ }^{4}$, Miklós Mézes ${ }^{5}$, Zoltán Prohászka ${ }^{3,4}$ and Attila Molvarec ${ }^{1}$

Addresses: ${ }^{1} 1$ st Department of Obstetrics and Gynecology, Semmelweis University, Budapest, Hungary, ${ }^{2}$ Research Group of Animal Breeding and Hygiene, Faculty of Animal Science, University of Kaposvár, Kaposvár, Hungary, ${ }^{3} 3$ rd Department of Internal Medicine and Szentágothai Knowledge Center, Semmelweis University, Budapest, Hungary, ${ }^{4}$ Research Group of Inflammation Biology and Immunogenomics, Hungarian Academy of Sciences, Budapest, Hungary and ${ }^{5}$ Department of Nutrition, Faculty of Agricultural and Environmental Sciences, Szent István University, Gödöllő, Hungary

E-mail: Levente Lazar* - lazar_levente@hotmail.com; RigóJánosJrrigo@noi1.sote.hu; Bálint Nagy - nabal@noi1.sote.hu; Krisztián Balogh - Balogh.Krisztian@mkk.szie.hu; Veronika Makó - vera.mako@gmail.com; László Cervenak - cela@kut.sote.hu; Miklós Mézes - Mezes.Miklos@mkk.szie.hu; Zoltán Prohászka - prohoz@kut.sote.hu; Attila Molvarec - molvarec@freemail.hu ${ }^{*}$ Corresponding author

Published: 21 November 2009

BMC Medical Genetics 2009, 10:120

doi: $10.1|86 /| 47 \mid-2350-10-120$

Received: II November 2008

Accepted: 21 November 2009

This article is available from: http://www.biomedcentral.com/I47/-2350/I0//20

(C) 2009 Lazar et al; licensee BioMed Central Ltd.

This is an Open Access article distributed under the terms of the Creative Commons Attribution License (http://creativecommons.org/licenses/by/2.0), which permits unrestricted use, distribution, and reproduction in any medium, provided the original work is properly cited.

\begin{abstract}
Background: The aim of our study was to examine whether increased circulating total cell-free DNA levels are related to the clinical characteristics and standard laboratory parameters of preeclamptic patients, to markers of inflammation, endothelial activation or injury, oxidative stress and to cell-free fetal DNA levels.

Methods: Circulating total cell-free DNA was measured by real-time quantitative PCR in plasma samples obtained from 67 preeclamptic and 70 normotensive pregnant women. Standard laboratory parameters, C-reactive protein, plasma von Willebrand factor antigen, plasma fibronectin, plasma malondialdehyde and cell-free fetal DNA levels were also determined.

Results and Conclusion: Circulating total cell-free and fetal deoxyribonucleic acid levels were significantly elevated in pregnancies complicated by preeclampsia (median: II.395 vs. 32.460 and $0.00 \mathrm{I}$ vs. $0.086 \mathrm{pg} / \mu \mathrm{l} ; \mathrm{P}<.00 \mathrm{I}$ ). The quantity of plasma total cell-free DNA did not correlate with most of the laboratory parameters, except for serum aspartate aminotransferase and alanine aminotransferase activities (correlation coefficient: $0.3 \mathrm{I} ; \mathrm{P}=0.0 \mathrm{I} 2$ and $0.46 ; \mathrm{P}<.00 \mathrm{I}$ ). There was no correlation with clinical characteristics, including body mass index. The releases of both free fetal and total cell-free deoxyribonucleic acid were found to be affected in preeclampsia. Hepatocellular necrosis seems to be responsible - at least partly - for increased circulating total DNA levels in preeclampsia, as suggested by the significant correlation with liver enzyme activities.
\end{abstract}




\section{Background}

Preeclampsia is one of the leading causes of maternal and perinatal morbidity and mortality in the developed world [1,2]. It is characterized by hypertension and proteinuria developing after midgestation in previously normotensive pregnant women. Although the exact etiology of preeclampsia remains elusive [2], there appears to be a defect in trophoblast invasion with diminished infiltration and modification of the spiral arteries leading to impaired placentation and subsequent uteroplacental insufficiency [3]. The ischemic and oxidatively stressed placenta releases proinflammatory (Th1) cytokines, lipid peroxidation products and trophoblast debris (syntitiotrophoblast microfragments, cytokeratin, soluble DNA and RNA of fetal origin and even trophoblast cells) into the maternal circulation, which in turn trigger an excessive maternal systemic inflammatory response [4-6]. The systemic inflammatory response with systemic oxidative stress and generalized endothelial dysfunction appears to be the cause of the maternal syndrome of preeclampsia [6]. Several maternal and familiar factors such as maternal age and body mass index, chronic hypertension or renal diseases, and hypertension in family history have been described as risk factors of preeclampsia. In the last ten years, several studies have reported the increased level of fetal cells, cell-free maternal and fetal DNA in the maternal circulation [7]. While the latter seems to reflect placental injury, the reason for increased cell-free maternal DNA levels in preeclampsia is currently unknown [8,9]. The aim of our study was to measure and compare the concentration of cell-free (cf) and cell-free fetal (cff) DNA levels in the plasma of preeclamptic and normotensive pregnant women, and to determine whether increased circulating of DNA levels are related to clinical characteristics and standard laboratory parameters of preeclamptic patients, to markers of inflammation (Creactive protein), endothelial activation (von Willebrand factor antigen) or endothelial injury (fibronectin), oxidative stress (malondialdehyde) and to cell-free fetal DNA levels.

\section{Methods \\ Patients}

This study was performed in a retrospective manner. Sixty-seven plasma samples were collected from women with preeclampsia during pregnancy; these samples were stored frozen. Preeclampsia was determined by a blood pressure of $\geq 140 / 90 \mathrm{mmHg}$ and an associated proteinuria of $\geq 300 \mathrm{mg} / 24 \mathrm{~h}$ after 20 weeks' gestation. Seventy samples were taken from normotensive women with normal pregnancies. All women were pregnant with a single fetus; 36 of those with preeclampsia had a single male fetus, as did 25 of the control cohort. Pregnant women with eclampsia or HELLP syndrome (hemolysis, elevated liver enzymes, and low platelet count) were not enrolled in this study. The study protocol was approved by the Regional Institutional Committee of Medical Ethics at the Semmelweis University, and written informed consent was obtained from each patient. The study was conducted in accordance with the Declaration of Helsinki.

\section{DNA extraction and PCR analysis}

Blood was collected into sterile EDTA tubes, and plasma was rapidly separated by centrifugation at $3000 \mathrm{~g}$ and stored frozen at $-80^{\circ} \mathrm{C}$ until the analyses were performed. DNA was extracted from $400 \mu \mathrm{L}$ plasma with the High Pure PCR Template Preparation Kit (Roche Diagnostics, Mannheim, Germany) according to the manufacturer's protocol. Strict anticontamination procedures were used throughout. These included the use of aerosol-resistant tips throughout all the experimental procedures and the addition of multiple negative control samples in each analysis. The DNA was eluted in $50 \mu \mathrm{L}$ of elution buffer solution, of which $2 \mu \mathrm{L}$ was used as a template for the PCR reaction.

\section{SYBR Green PCR analysis}

For the SYBR Green real-time PCR analysis, we used a LightCycler 1.0 System (Roche Diagnostics, Mannheim, Germany). Circulating male fetal DNA was detected with the following primers for the SRY gene located on the Y chromosome: forward, SRY F, 5'-ggc aac gtc cag gat aga gtg a-3', reverse $5^{\prime}$-tgc tga tct ctg agt ttc gca tt- $3^{\prime}$. To determine the total amount of circulating DNA present in the maternal plasma samples, we used a SYBR Green assay and primers for the globin gene, which is present in all genomes. In this analysis, the following primers were used: forward $5^{\prime}$-aca caa ctg tgt tca cta gc- $3^{\prime}$, reverse $5^{\prime}$-caa ctt cat cca cgt tca cc-3'. The PCR analysis was carried out in $10-\mu \mathrm{L}$ reaction volumes containing $1 \mu \mathrm{L}$ DNA, 2,5 pmol/L of each amplification primer, $2 \mu \mathrm{l}$ of DNA Master SYBR Green I mix (LightCycler FastStart DNA Master SYBR Green I kit: Taq polymerase, $\mathrm{dNTP}, \mathrm{MgCl}_{2}$ ), and $6 \mu$ l of nuclease free water.

The analysis was designed in such a manner that identical thermal profiles could be used for both the SRY and globin SYBR Green assays, because this allowed us to analyze both of these markers on the same plate in the same analytic run. The PCR was carried out in 40 cycles under the following conditions: initial denaturation $8 \mathrm{~min}$ on $95^{\circ} \mathrm{C}, 5 \mathrm{sec}$ denaturation on $95^{\circ} \mathrm{C}, 10 \mathrm{sec}$ annealing on $60^{\circ} \mathrm{C}, 15$ sec extension on $72^{\circ} \mathrm{C}$, cooling to $4^{\circ} \mathrm{C}$ till capillar removement. To determine the number of copies of circulating DNA present in the plasma sample, a standard dilution curve with a known 
concentration of male genomic DNA was used. All samples were analyzed in duplicate and scored in a blinded manner.

\section{Laboratory parameters}

Standard laboratory parameters (clinical chemistry) and C-reactive protein (CRP) levels were determined by an autoanalyzer (Cobas Integra 800, Roche, Mannheim, Germany) using the manufacturer's kits. Plasma von Willebrand factor antigen (VWF:Ag) levels were quantified by ELISA (Dakopatts, Glostrup, Denmark), while plasma fibronectin concentration by nephelometry (Dade Behring, Marburg, Germany), according to the manufacturer's instructions. Plasma malondialdehyde levels were measured by the thiobarbituric acid-based colorimetric assay [10].

\section{Data analysis}

The normality of continuous variables was assessed using the Shapiro-Wilk's W-test. As the continuous variables were not normally distributed, nonparametric statistical methods were used. To compare continuous variables between the two groups, the Mann-Whitney U-test was applied, while to compare categorical variables between the groups, the Fisher exact and Pearson $\chi^{2}$ tests were performed. As plasma total and fetal DNA levels showed skewed distributions, we performed analyses of covariance (ANCOVA) with logarithmically transformed data. The Spearman rank order correlation was used to calculate correlation coefficients. Statistical analyses were carried out using the following software: STATISTICA (version 7.1; StatSoft, Inc., Tulsa, Oklahoma, USA) and Statistical Package for the Social Sciences (version 15.0 for
Windows; SPSS, Inc., Chicago, Illinois, USA). For all statistical analyses, $\mathrm{p}<0.05$ was considered statistically significant.

\section{Results}

In this study, performed retrospectively and in a blinded manner, 67 plasma samples were obtained from pregnant women with preeclampsia. Thirty-six of them carried male fetuses (gestational age at blood draw, median (range): 37.5 (30-41)). Seventy plasma samples were obtained as control from normotensive pregnant women, 25 of whom carried male fetuses (gestational age at blood draw, median (range): 36 (29-39)).

The clinical characteristics of the studied pregnant women are shown in Table 1. The measured laboratory parameters were significantly different between the two groups, except for serum AST activities (Table 2). Quantifying the amount of $\mathrm{Y}$ chromosome-specific DNA, we were able to confirm that the levels of male fetal DNA were significantly elevated in pregnancies complicated by preeclampsia compared to the normotensive control subjects (median: $0.086 \mathrm{pg} / \mu \mathrm{l}$ vs. 0.001 $\mathrm{pg} / \mathrm{\mu l}$ plasma; $P<.001 ;$ Figure 1$)$. Data regarding the quantity of total cell-free DNA (globin) also confirmed significant difference between the two groups (median: $32.460 \mathrm{pg} / \mu \mathrm{l}$ vs. $11.395 \mathrm{pg} / \mu \mathrm{l}$ plasma; $P<.001$; Figure 2 ). As BMI and gestational age at blood sampling, which are known to affect plasma DNA levels, differed significantly between the preeclamptic and the control group, adjusted values were calculated with analyses of covariance (ANCOVA). The differences in fetal and total cellfree DNA levels between the two study groups remained

Table I: Clinical characteristics of normotensive, healthy pregnant women and preeclamptic patients

\begin{tabular}{|c|c|c|c|}
\hline Variable & Controls $(n=70)$ & Preeclampsia $(n=67)$ & Statistical significance ( $p$ value) \\
\hline Age (years) & $30(17-44)$ & $29(19-42)$ & NS \\
\hline BMI at blood draw $\left(\mathrm{kg} / \mathrm{m}^{2}\right)$ & $25.9(19.0-42.0)$ & $30.0(20.6-38.3)$ & $<0.001$ \\
\hline Smokers & $0(0 \%)$ & $3(4.5 \%)$ & NS \\
\hline Primiparas & $45(64.3 \%)$ & $43(64.2 \%)$ & NS \\
\hline Systolic blood pressure $(\mathrm{mmHg})$ & $110(80-138)$ & $160(135-220)$ & $<0.001$ \\
\hline Diastolic blood pressure $(\mathrm{mmH})$ & $70(55-86)$ & $100(90-131)$ & $<0.001$ \\
\hline Gestational age at blood draw (weeks) & $35(20-40)$ & $38(30-4 I)$ & $<0.001$ \\
\hline Gestational age at delivery (weeks) & $39(35-4 I)$ & $38(33-4 I)$ & $<0.05$ \\
\hline Fetal birth weight (grams) & $3500(2650-4400)$ & $3200(1400-4200)$ & $<0.001$ \\
\hline Fetal growth restriction & $0(0 \%)$ & $\mathrm{II}(16.4 \%)$ & $<0.001$ \\
\hline
\end{tabular}

Data are presented as median (range) for continuous variables and as number (percent) for categorical variables. NS: not significant; BMI: body mass index. 
Table 2: Laboratory parameters of normotensive, healthy pregnant women and preeclamptic patients

\begin{tabular}{|c|c|c|c|}
\hline Variable & Controls $(n=70)$ & Preeclampsia $(n=67)$ & Statistical significance ( $p$ value) \\
\hline Serum BUN level (mmol/l) & $2.7(1.7-4.8)$ & $3.4(0.8-6.5)$ & $<0.001$ \\
\hline Serum creatinine level $(\mu \mathrm{mol} / \mathrm{l})$ & $47(34-79)$ & $63(36-95)$ & $<0.001$ \\
\hline Serum bilirubin level $(\mu \mathrm{mol} / \mathrm{l})$ & $5.1(1.8-15.2)$ & $7.4(2.1-20.9)$ & $<0.001$ \\
\hline Serum AST activity (U/I) & $19(10-38)$ & $19(10-148)$ & NS \\
\hline Serum ALT activity $(\mathrm{U} / \mathrm{I})$ & $12(7-32)$ & $15(6-233)$ & $<0.05$ \\
\hline Serum LDH activity $(\mathrm{U} / \mathrm{I})$ & $159(93-211)$ & $192(113-403)$ & $<0.001$ \\
\hline Serum CRP level (mg/l) & $3.6(0.5-28.0)$ & $6.7(0.3-36.9)$ & $<0.05$ \\
\hline Plasma VWF:Ag level (\%) & $129.3(47.8-297.1)$ & I87.I (43.3-423.0) & $<0.001$ \\
\hline Plasma fibronectin level $(g / l)$ & $0.33(0.14-0.84)$ & $0.58(0.02-2.13)$ & $<0.001$ \\
\hline Plasma malondialdehyde level $(\mathrm{nmol} / \mathrm{ml})$ & $14.74(6.19-36.52)$ & $18.62(10.75-24.65)$ & $<0.001$ \\
\hline Plasma total DNA level $(\mathrm{pg} / \mu \mathrm{l})$ & $11.395(0.425-256.3)$ & $32.460(1.670-602.7)$ & $<0.001$ \\
\hline 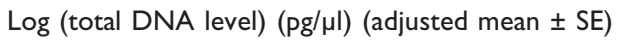 & $1.145 \pm 0.066$ & $1.513 \pm 0.086$ & $<0.05$ \\
\hline Plasma fetal DNA level $(\mathrm{pg} / \mu \mathrm{l})$ & $0.001(0.0-0.845)^{\dagger}$ & $0.086(0.002-3.200)^{\ddagger}$ & $<0.001$ \\
\hline Log (fetal DNA level) $(\mathrm{pg} / \mu \mathrm{l})$ (adjusted mean $\pm \mathrm{SE})$ & $-2.705 \pm 0.310^{\dagger}$ & $-0.994 \pm 0.326^{\ddagger}$ & $<0.05$ \\
\hline
\end{tabular}

Data are presented as median (range) for continuous variables.

NS: not significant; SE: standard error; BUN: blood urea nitrogen; AST: aspartate aminotransferase; ALT: alanine aminotransferase; LDH: lactate dehydrogenase; CRP: C-reactive protein; VWF:Ag: von Willebrand factor antigen; DNA: deoxyribonucleic acid.

$t_{n}=25$.

$\neq \mathrm{n}=36$.

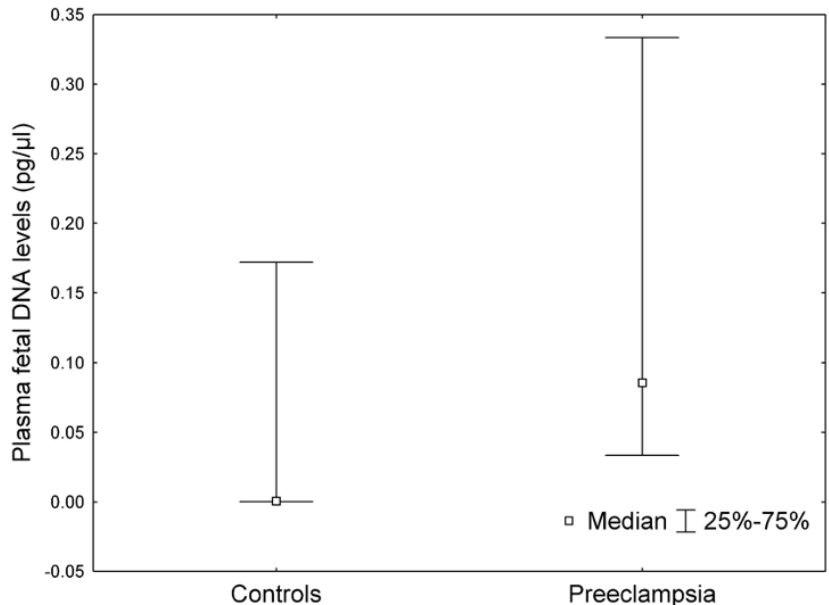

Figure I

Plasma fetal deoxyribonucleic acid (DNA) levels in normotensive, healthy pregnant women and preeclamptic patients. Middle point: median, whisker: 25-75 percentile.

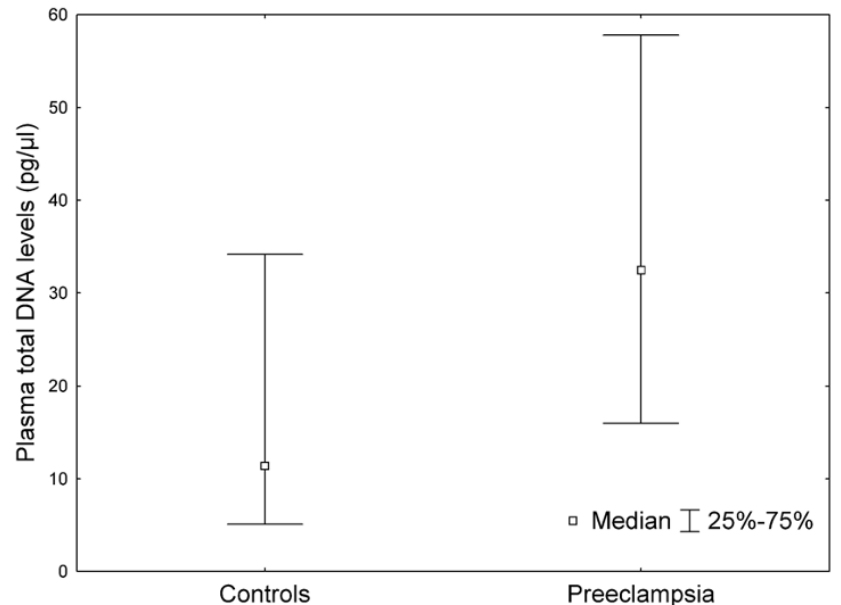

Figure 2

Plasma total deoxyribonucleic acid (DNA) levels in normotensive, healthy pregnant women and preeclamptic patients. Middle point: median, whisker: 25-75 percentile. 
significant even after adjustment for maternal age, BMI and gestational age at blood draw in ANCOVA (Table 2).

Correlation coefficients with $\mathrm{p}$ values between clinical characteristics and laboratory parameters of preeclamptic patients and plasma total DNA levels are presented in Table 3. Total cell-free DNA levels showed no significant correlations with the clinical characteristics of preeclamptic patients, including BMI. Furthermore, the quantity of total plasma free DNA did not correlate with most of the laboratory parameters including plasma cff DNA levels, except for serum aspartate aminotransferase and alanine aminotransferase activities (correlation coefficient: $0.31 ; P=0.012$ and $0.46 ; P<.001$ ).

Table 3: Correlation coefficients with $p$ values between clinical characteristics and laboratory parameters of preeclamptic patients and plasma total DNA levels

\begin{tabular}{lll}
\hline Variable & $\begin{array}{l}\text { Correlation } \\
\text { coefficient }\end{array}$ & $\begin{array}{l}\text { Statistical } \\
\text { significance } \\
\text { ( } \mathbf{p ~ v a l u e ) ~}\end{array}$ \\
\hline Age & -0.04 & 0.72 \\
\hline BMI at blood draw & 0.18 & 0.23 \\
\hline Systolic blood pressure & -0.10 & 0.43 \\
\hline Diastolic blood pressure & -0.21 & 0.087 \\
\hline Gestational age at blood draw & 0.10 & 0.40 \\
\hline Gestational age at delivery & 0.02 & 0.87 \\
\hline Fetal birth weight & -0.01 & 0.96 \\
\hline Serum BUN level & -0.07 & 0.57 \\
\hline Serum creatinine level & 0.03 & 0.83 \\
\hline Serum bilirubin level & 0.06 & 0.62 \\
\hline Serum AST activity & $\mathbf{0 . 3 1}$ & $\mathbf{0 . 0 1 2}$ \\
\hline Serum ALT activity & $\mathbf{0 . 4 6}$ & $<0.001$ \\
\hline Serum LDH activity & 0.17 & 0.23 \\
\hline Serum CRP level & 0.04 & 0.76 \\
\hline Plasma VWF:Ag level & -0.18 & 0.14 \\
\hline Plasma fibronectin level & 0.01 & 0.96 \\
\hline Plasma malondialdehyde level & -0.11 & 0.41 \\
\hline fMI: & 0.14 & \\
\hline
\end{tabular}

BMI: body mass index; BUN: blood urea nitrogen; AST: aspartate aminotransferase; ALT: alanine aminotransferase; LDH: lactate dehydrogenase; CRP: C-reactive protein; VWF:Ag: von Willebrand factor antigen; DNA: deoxyribonucleic acid.

$\ddagger \mathrm{n}=36$.
The sample size of the preeclamptic group allowed us to detect a correlation coefficient (rho) of 0.30 or higher, at a Type I error rate of 0.05 , with a statistical power of at least $80 \%$.

\section{Comment}

Several papers described previously that fetal-maternal cell trafficking was significantly disturbed in pregnancies complicated by preeclampsia, with elevated numbers of fetal cells detected in the maternal circulation during these pregnancies [11-13]. Lo et al. [14] showed that the fetal circulating DNA level was elevated in a similar manner during pregnancies complicated by preeclampsia [5]. We were able to confirm the latter observation in this study by showing that the levels of circulating total and fetal DNA were significantly elevated in women with preeclampsia compared to the control group. Our study also confirmed that the quantification of fetal and total circulating DNA by real-time PCR was both reliable and reproducible. In addition to previous findings, with collected data regarding clinical characteristics and measuring different laboratory parameters specific to renal and liver function, inflammation, endothelial activation/damage and oxidative stress, we were able to analyze the correlation between the quantity of cell-free DNA and these parameters first in the literature. Although the exact mechanism leading to the release of free extracellular DNA into the circulation is not yet clear [15], currently the most favored explanation for the release of DNA fragments is through apoptosis or some other form of cell death [16-18]. Some other studies, however, have indicated that a normal physiological process may be involved in the release of free circulating DNA [15]. In contrast to Zhong et al. [8], we did not find a correlation between of DNA and cff DNA levels, which indicates that the amount of circulating total and fetal DNA does not increase similarly in preeclampsia. Indeed, the median plasma level of total DNA was 2.85 times higher in our preeclamptic group, while that of fetal DNA elevated 86-fold in preeclampsia. The latter seems to reflect extensive placental injury in the disease. The clinical characteristics of our preeclamptic patients, including body mass index, did not affect plasma total DNA concentrations, which is at variance with previous observations. Our data did not confirm any correlation between the markers of endothelial cell activation/ damage and the level of total cell-free DNA, which suggests that the elevation of the DNA amount is caused by another mechanism and the previously suggested endothelial dysfunction is not the primary cause that leads to the increased plasma DNA level observed in preeclampsia. Inflammatory cytokines and reactive oxygen species might damage cellular membranes and DNA 
in preeclampsia. Nevertheless, total cell-free DNA levels were not related to markers of inflammation and oxidative stress in our preeclamptic group. Instead, only liver enzyme activities showed significant correlations with plasma total DNA levels, which suggests that hepatocellular necrosis might account - at least in part for increased circulating total DNA levels in preeclampsia. Interestingly, plasma total DNA levels were found previously to be significantly higher in HELLP syndrome than in preeclampsia without HELLP syndrome [19]. HELLP syndrome is characterized by extensive tissue damage (hepatocellular necrosis and hemolysis), which supports the hypothesis that cellular necrosis might be responsible for increased cell-free DNA levels in the maternal circulation, at least in preeclampsia. However, it is also possible that another unrelated mechanism, such as release from activated granulocytes and other white blood cells, accounts primarily for the increase in circulating DNA levels associated with preeclampsia. The lack of correlation between increased circulating total DNA levels and several measured laboratory markers in preeclampsia could not completely exclude the relationship of cell-free DNA with the corresponding pathological processes. The release rate, clearance rate and half-lives of the investigated markers may be different from those of cell-free DNA, which might also explain the lack of correlation. More detailed studies will be necessary to elucidate the underlying mechanisms and biochemical background of this medically relevant disorder. Our results provide some new data for further investigations.

\section{Competing interests}

The authors declare that they have no competing interests.

\section{Authors' contributions}

LL made substantial contributions to conception and design of study and carried out the molecular genetic studies. RJJr made the manuscript revising. NB carried out the molecular genetic studies. BK carried out the immunoassays. MVcarried out the sample collection. CL made the analysis and interpretation of data. MM participated in its design and coordination. PZ carried out the immunoassays. MA has participated in the design of the study and performed the statistical analysis. All authors read and approved the final manuscript.

\section{References}

I. Witlin AG and Sibai BM: Hypertension in pregnancy: current concepts of preeclampsia. Annu Rev Med 1997, 48:I I5-127.

2. Dekker GA and Sibai BM: Etiology and pathogenesis of preeclampsia: current concepts. Am J Obstet Gynecol 1998, 179:1359-1375

3. Lim KH, Zhou Y, Janatpour M, McMaster M, Bass K and Chun SH: Human cytotrophoblast differentiation/invasion is abnormal in pre-eclampsia. Am J Pathol 1997, | 5 I:|809-18|8.

4. Redman CW and Sargent IL: The pathogenesis of pre-eclampsia. Gynecol Obstet Fertil 200I, 29:518-522.
5. Rusterholz C, Hahn S and Holzgreve W: Role of placentally produced inflammatory and regulatory cytokines in pregnancy and the etiology of preeclampsia. Semin Immunopathol 2007, 29:151-162.

6. Redman CW, Sacks GP and Sargent IL: Preeclampsia: an excessive maternal inflammatory Response to pregnancy. Am J Obstet Gynecol 1999, 180:499-506.

7. Zhong $X Y$, Laivuori H, Livingston JC, Ylikorkala O, Sibai BM, Holzgreve $W$ and Hahn S: Elevation of both maternal and fetal extracellular circulating deoxyribonucleic acid concentrations in the plasma of pregnant women with preeclampsia. Am J Obstet Gynecol 200I, 3:4 14-4I9.

8. Holzgreve $W$ and Hahn S: Novel molecular biological approaches for the diagnosis of preeclampsia. Clin Chem 1999, 45:45I-452.

9. Korabecna M, Opatrna S, Wirth J, Rulcova K, Eiselt J, Sefrna F and Horinek A: Cell-free plasma DNA during peritoneal dialysis and hemodialysis and in patients with chronic kidney disease. Ann N Y Acad Sci 2008, I I37:296-30I.

10. Placer ZA, Cushman LL and Johnson BC: Estimation of product of lipid peroxidation (malonyl dialdehyde) in biochemical systems. Anal Biochem 1966, 16:359-64.

II. Wataganara T and Bianchi DW: Fetal cell-free nucleic acids in the maternal circulation: new clinical applications. Ann $N$ Y Acad Sci 2004, 1022:90-99.

12. Gänshirt D, Smeets FW, Dohr A, Walde C, Stehen I and Lapucci C, et al: Enrichment of fetal nucleated red blood cells from the maternal circulation for prenatal diagnosis: experiences with triple density gradient and MACS based on more than 600 cases. Fetal Diagn Ther 1998, 13:276-286.

13. Swinkels DW, de Kok JB, Hendriks JC, Wiegerinck E, Zusterzeel PL and Steegers EA: Hemolysis, elevated liver enzymes, and low platelet count (HELLP) syndrome as a complication of preeclampsia in pregnant women increases the amount of cell-free fetal and maternal DNA in maternal plasma and serum. Clin Chem 2002, 48:650-653.

14. Holzgreve W, Ghezzi F, Di Naro E, Maymon E, Gänshirt D and Hahn S: Disturbed fetomaternal cell traffic in preeclampsia. Obstet Gynecol 1998, 9 I:669-672.

15. Lo YM, Leung TN, Tein MS, Sargent IL, Zhang J and Lau TK, et al: Quantitative abnormalities of fetal DNA in maternal serum in preeclampsia. Clin Chem 1999, 45: I84-188.

16. Anker P, Mulcahy $H$, Chen XQ and Stroun M: Detection of circulating tumour DNA in the blood (plasma/serum) of cancer patients. Cancer Metastasis Rev 1999, 18:65-73.

17. Bret L, Lule J, Alary C, Appolinaire-Pilipenko S, Pourrat JP and Fournie GJ: Quantitation of blood plasma DNA as an index of in vivo cytotoxicity. Toxicology 1990, 61:283-292.

18. Holdenrieder S, Stieber P, Forg T, Kuhl M, Schulz L and Busch M, et al: Apoptosis in serum of patients with solid tumours. Anticancer Res 1999, 19:2721-2724.

19. DiFederico E, Genbacev $O$ and Fisher SJ: Preeclampsia is associated with widespread apoptosis of placental cytotrophoblasts within the uterine wall. Am J Pathol 1999, |55:293-30।.

\section{Pre-publication history}

The pre-publication history for this paper can be accessed here:

http://www.biomedcentral.com/1471-2350/10/120/prepub 